\title{
POLLUTION ACROSS CHINESE PROVINCES
}

By

Catherine Yap Co ${ }^{1 / 2 /}$ Fanying Kong ${ }^{3 /}$ Shuanglin Lin ${ }^{2 / 4 /}$

August 27, 2007

\begin{abstract}
We revisit the environmental Kuznets curve (EKC) hypothesis using 1987-1995 data for Chinese provinces. A comparison of off-sample (1996-2004) predictions to actual emissions indicates that more stringent rules are still needed to fight industrial (waste water and dust) pollution. Auxiliary regressions show that conditional on income, northern provinces have lower industrial waste water pollution; non-coastal and provinces with smaller secondary industry shares have lower industrial (waste water, COD, and dust) pollution; provinces with smaller state-owned enterprises share have lower industrial COD pollution; and, commitment to control industrial dust pollution is correlated with local governments’ budget balance.
\end{abstract}

Keywords: environmental Kuznets curves; Chinese provinces JEL Classifications: Q53; O13

${ }^{1 /}$ Corresponding author. ${ }^{2 /}$ Department of Economics, University of Nebraska at Omaha, Omaha, Nebraska, 68182. ${ }^{3 /}$ Department of Sociology, Midland Lutheran College, Fremont, Nebraska 68025. "/ China Center for Public Finance, School of Economics, Peking University, Haidian, Beijing, China, 100871. We would like to thank Miaomiao Yu for invaluable research assistance; Wang Xiaoping for help in collecting some of the pollution data; and, Fidel Gonzalez and participants at the "Modeling Pollution Effects" session of the 2007 Eastern Economics Association Conference (February 23, New York City, NY) for comments on an earlier draft. 


\section{Introduction}

The market-oriented economic reforms that started in 1978 have greatly transformed the Chinese economy. State-owned enterprises (SOEs) were allowed to operate and compete on free market principles, rather than under the direction and guidance of state planning; special economic zones were established along the coast for the purpose of attracting foreign direct investment, boosting exports, and importing high technology products; and, private enterprises were legalized and promoted. With these reforms, the average annual growth rate of China's real GDP was close to $10 \%$ from 1979 to 2005 , compared to a pre-reform growth rate of around $5 \%$ from 1960 to 1978 . No country has ever lifted more people out of poverty faster than China since the adoption of these reforms. However, economic growth in China has been accompanied by severe environmental deterioration.

According to The Economist (2004), the World Bank estimates that direct damages from pollution (e.g., medical bills) are 8-12\% of China’s annual GDP. The World Bank has identified 16 of the 20 most polluted cities in the world to be located in China. And, close to two-thirds of the 300 cities tested by China's environmental protection agency failed to meet the air quality standards set by the World Health Organization. With negligent environmental protection, some areas have such high levels of toxins in the air and groundwater that cancer levels are 15 to 30 times higher than the national figure (see Lynch 2005). ${ }^{1}$ Unsustainable environmental practices also pose increasing threats to China's water, forests, biodiversity, and food and energy supplies. Since China is a huge country, its pollution problems undoubtedly have serious negative effects on the global environment. ${ }^{2}$

\footnotetext{
${ }^{1}$ Economy (2004) also provides a description of the health effects of pollution in China.

2 See The Economist (2007) for a popular account of how China's pollution problems affect the rest of the world.
} 
Currently, forces that oppose more stringent rules and regulations in the name of free markets and economic growth are battling forces that favor greater environmental protection. It appears that the latter group is losing the battle. The general public and the central government tend to favor more stringent environmental rules while local governments do not. ${ }^{3}$ The current central and local government tax revenue sharing scheme is one reason why local governments in China have little incentive to call for more stringent environmental policies. Since 1994, local governments have experienced budget deficits every year, and they have come to rely heavily on central government transfers. ${ }^{4}$ These transfers are largely dependent on value-added tax rebates. Since value-added tax rebates are related to local output increases, local governments in China have strong incentives to increase production (thereby increasing revenue transfers), ${ }^{5}$ but have little incentive to protect the environment.

In this paper, we revisit the environmental Kuznets curve (EKC) hypothesis. According to the EKC hypothesis, an inverted-U characterizes the income-emission relationship. ${ }^{6}$ However, a number of studies (e.g., Millimet et al. 2003) have shown that a cubic relationship may exist between income and emissions. In particular, they may again be positively correlated at still higher income levels.

\footnotetext{
${ }^{3}$ According to Cheng et al. (2007), a recent survey indicates that $86 \%$ of the people are not satisfied with China's environmental protection; $70 \%$ of the people blame local governments for the environmental problems; and, 78\% of the people indicate willingness to sacrifice the speed of growth for a better environment.

${ }^{4}$ Even rich provinces largely depend on transfers from the central government to cover their budget deficits. For example in 2004, $42 \%$ of Shanghai's budgetary revenues are rebates from the central government; the rate for Jiangsu province is $48 \%$.

${ }^{5}$ Another reason is that Chinese local government officials are appointed by their superiors based mainly on local economic performance.

${ }^{6}$ See Grossman and Krueger (1995) for an early contribution. One of the explanations for the inverted-U EKC is that when regions reach a sufficiently high income level, people living in these regions will demand cleaner environments (and, these regions also have the necessary institutions to enforce extant environmental rules); thus, emissions decline as income increases beyond this point. See De Bruyn and Heintz (1999) for a review.
} 
Our strategy is to first estimate EKCs using fixed effects panel regression using data for 30 Chinese provinces from 1987 to $1995 .^{7}$ We end the data coverage of the EKC estimations in 1995 since a number of amendments to pollution laws were introduced after this year. This allows us to determine the trajectory of selected pollutants relative to income after 1995 if no changes to pollution policy occur (i.e., make off-sample predictions of pollution discharges using the estimated EKCs). We then compare these off-sample predictions to actual pollution discharges in 1996 to 2004 to partly quantify any effect pollution policy changes may have had on emissions.

A comparison of the off-sample predictions to actual pollution discharges in 1996 to 2004 indicates that, actual industrial chemical oxygen demand (COD) pollution per capita discharge rates in 1996-2004 have leveled off and do not increase with income as the estimated EKC predicts. Thus, environmental policies enacted by the Chinese government to control industrial COD pollution may have been partly successful. However, actual industrial waste water per capita discharge rates in 1996-2004 increase with income; this is opposite the prediction of the EKC. Also, actual industrial dust per capita discharge rates in 1996-2004 are larger than the predicted per capita discharge rates for most of the provinces. This is inconsistent with the notion that given the adoption of stricter environmental regulations, actual emissions should be lower than the EKC predictions because the latter assumes no changes in environmental regulations.

Auxiliary regressions of the estimated province-specific fixed effects against several province characteristics show that conditional on income, northern provinces have lower levels of industrial waste water pollution (thus, may have been more willing to regulate this type of

\footnotetext{
${ }^{7}$ To be precise, Beijing, Tianjin, and Shanghai are municipalities while Inner Mongolia, Guangxi, Tibet, Ningxia, and Xinjiang are Minority Autonomous Regions. We refer to all of these areas as provinces for convenience. Chongqing became a municipality in 1997 (it is part of Sichuan province in our data).
} 
pollution); non-coastal provinces and provinces with smaller secondary industry shares have lower levels of three types of pollutants; provinces with smaller state-owned enterprises share have lower levels of industrial COD pollution; finally, there is some evidence that a province's industrial dust pollution level (thus, its commitment to control pollution) is related to its budget balance.

To put the current study in perspective, the environmental consequences of economic growth and policy responses to environmental problems since the establishment of the People's Republic of China are briefly described in the next section. In Section III, a detailed description of the data and empirical methodology used are provided. The results are analyzed in section IV. Concluding remarks are presented in the last section.

\section{Pollution and Environmental Policy in China}

Since the founding of the People's Republic of China, environmental degradation has accompanied economic growth. During the Great Leap Forward (1958-1960), people's communes were established in rural China. Trees were cut and used as fuel to make steel, causing a reduction in forest coverage. During the Cultural Revolution (1966-1976), farmers in the communes were mobilized to build terra fields in mountains to increase arable farmland, damaging the green coverage of mountains. ${ }^{8}$ During the period of economic reforms that started in 1978, communes were dissolved and farmers and herdsmen were given freedom to engage in industrial production. SOEs became profit-oriented and private enterprises emerged. Using mostly outdated technologies, the emergence of these enterprises increased pollution in China substantially.

\footnotetext{
${ }^{8}$ Also see Edmonds (1999).
} 
It was only in 1995 that the central government fully realized the urgency of environmental problems in China. A number of environmental laws were amended to signal their strong commitment to protect the environment. For example, the Law on the Prevention and Control of Water Pollution was amended in 1996; the Law on the Prevention and Control of Atmospheric Pollution was amended in 1995 and 2000. ${ }^{9}$ According to the Law on Prevention and Control of Water Pollution, all activities of any person or unit polluting surface and underground water shall be punished with a fine. The Law on the Prevention and Control of Atmospheric Pollution sets standards for air pollution from burning coal, automobiles, and dust; it also specifies measures to punish violators.

Environmental policymaking devolved from the central government to local governments in the 1980s. This has introduced some amount of heterogeneity in environmental policy and enforcement across China’s provinces. ${ }^{10}$ For example, in 1998 Jiangsu passed the Regulations on Protection of Agricultural Ecology and Environment making dumping polluted water in agricultural areas illegal. ${ }^{11}$ In 1998, Guangdong province passed the Regulations on Zhujiang Triangle Water Protection. This regulation set strict measures to punish water polluters. ${ }^{12}$

The passage of the Cleaner Production Promotion Law in 2002 is another signal of China's commitment to a path of sustainable development. ${ }^{13}$ This has been preceded by a

\footnotetext{
${ }^{9}$ National People's Congress of the People's Republic of China, Amendment to the Law on the Prevention and Control of Water Pollution, May 15, 1995; and, National People's Congress of the People's Republic of China, The Law on Prevention of Air Pollution, April 29, 2000. English translations of these laws are available from the State Environmental Protection Administration's (SEPA) website at www.zhb.gov.cn/english/. According to Wang and Wheeler (2005), China's water pollution standards are stricter than those pertaining to air pollution. Muldavin (2000) provides an overview of China's environmental policy after 1949. Also see Ma and Ortolano (2000) for a detailed description of environmental regulations in China.

${ }^{10}$ See MacBean (2007), Economy (2004), Muldavin (2000), and Ma and Ortolano (2000) for details.

${ }^{11}$ See the $9^{\text {th }}$ Standing Committee of Jiangsu People's Congress, $7^{\text {th }}$ session, the Regulations on Protection of Agricultural Ecology and Environment, December 29, 1998 (Revised June 7, 2004).

${ }^{12}$ See the $9^{\text {th }}$ Standing Committee of Guangdong People's Congress, $6^{\text {th }}$ session, the Regulations on Zhujiang Triangle Water Protection, November 27, 1998.

${ }^{13}$ Cleaner production (CP) is referred to as pollution prevention (P2) in the United States. In 1990, the United States passed the Pollution Prevention Act. Prior to this legislation, pollution control efforts were focused at the "end-of-
} 
number of other environmental legislations with cleaner production provisions such as the Law on the Prevention and Control of Water Pollution amended in 1996 (Article 22) and by the Law on the Prevention and Control of Atmospheric Pollution amended in 2000 (Article 19). Both legislations contain provisions encouraging firms to adopt cleaner production technologies to reduce pollution discharge.

Since a number of environmental laws were amended after 1995, we study the time path of various pollutants in two periods: 1987-1995 and 1996-2004. Table 1 presents summary statistics for per capita emissions across 30 Chinese provinces for various pollutants. ${ }^{14}$ Means tests of the per capita emissions data show that the mean per capita discharge for three of the pollutants considered (industrial waste water, industrial COD, and smoke) declined between these two periods. Can this partly be attributed to changes in environmental laws enacted after 1995? Also, conditional on provinces’ income levels, what other factors correlate with pollution discharges? These, and other, questions are tackled in the succeeding sections.

\section{Table 1 near here}

\section{Data and Empirical Methodology}

Data

Pollution discharge data for 1987 to 1995 are obtained from the Economics of Industrial Pollution Control research team of Development Research Group (DECRG) at the World Bank. Data are downloadable at www.worldbank.org/nipr/data/china/status.htm. The data compiled by

\footnotetext{
the-pipe.” P2 refocuses pollution control efforts to the early stages of production whereby firms are encouraged to use production techniques that prevent pollution at the source.

${ }^{14}$ Industrial COD is the most important water pollutant in China (Wang and Wheeler 2003); and, is commonly used as a measure of water quality. Sulfur dioxide is of concern because it contributes to acid rain. It is released primarily from burning fuels that contain sulfur (e.g., coal). Smoke and industrial dust pollution are also important concerns in China as a number of the provisions (e.g., Article 30) in the Prevention and Control of Atmospheric Pollution Law address these pollutants.
} 
the World Bank are from two sources: China Environmental Quality Report and China Environment Yearbook. Pollution discharge data for 1996 to 2004 are obtained from various editions of the China Environment Yearbook. From Table 1, it is evident that pollution data for 1996-2004 are sparse. Waste gas data are no longer available and data for sulfur dioxide and smoke are incomplete. Gross regional product (in current yuan) and the general consumer price index $(1950=100)$ data are obtained from the China National Bureau of Statistics, China Compendium of Statistics 1949-2004.

Each province’s ranking (from cleanest to dirtiest) in 1987-1995 for all pollution media appear in Table 2. For the most part, Tibet is the cleanest province while Liaoning is the dirtiest province. The Southwest region is the cleanest region while the Northeast region is the dirtiest one. ${ }^{15}$ Coastal provinces are dirtier-in four of the six pollution media, the mean rank of coastal provinces range from 17 (waste gas) to 22 (industrial COD) while the mean rank of non-coastal provinces range from 11 (industrial COD) to $14\left(\mathrm{SO}_{2}\right)$. Non-coastal provinces ranked higher (dirtier) on average for smoke and industrial dust. Northern provinces ranked higher (dirtier) in all pollution media except industrial waste water. The mean ranks for Northern provinces range from 14 (industrial waste water) to 22 (smoke). For Southern provinces, the mean ranks range from 9 (smoke) to 17 (industrial waste water).

Table 3 contains the Spearman rank correlation coefficients of the various pollutants for 1987-1995. The rank correlations range from 0.02 (industrial COD and industrial dust) to 0.83 (waste gas and smoke). Not surprisingly, the rank correlations are high among the various types of gas pollutants but low between water and gas pollutants. Also, although provinces with high

\footnotetext{
${ }^{15}$ Shanghai is the dirtiest province and the Central and South region is the cleanest region if median ranks are used instead of mean ranks.
} 
water quality also tend to have high air quality, this relationship is not that strong (the rank correlation between industrial waste water and waste gas is 0.38$).{ }^{16}$

Tables 2 and 3 near here

\section{Empirical Methodology}

The following one-way fixed effects panel model is estimated:

$$
\begin{aligned}
& \text { poll }_{i t}=\alpha_{i}+\text { Bincome }_{i t}+\gamma \text { income }_{i t}{ }^{2}+\text { sincome }_{i t}{ }^{3}+\varepsilon_{i t}, \\
& i=1, \ldots, 30 ; t=1, \ldots, 9
\end{aligned}
$$

where $i$ indexes provinces and $t$ indexes time; poll $i t$ is one of the six pollutants measured in per capita terms in 1987 to 1995; income is real per capita gross regional product for province $i$ at time $t ; \beta, \gamma$, and $\delta$ are coefficient parameters; $\alpha_{i}$ are province-specific fixed effects; ${ }^{17}$ and, $\varepsilon_{\mathrm{ij}}$ is a well-behaved error term. We also estimate a quadratic specification for comparison.

We do realize that besides income, a number of other factors, such as environmental regulations, output composition, and the relative importance of state-owned enterprises, may affect pollution emissions across provinces. ${ }^{18}$ However, these factors are somehow related to income; thus, following standard practice (see e.g., List and McHone 2000; Millimet et al. 2003)

\footnotetext{
${ }^{16}$ Gas pollution in China is mostly from the use of coal and wood as fuels and from automobiles, while water pollution is mainly from pulp and paper, metallurgical, and chemical factories (see Naughton 2007). In the late 1980s and the early 1990s, the environmental issue had not been emphasized. Thus, provinces with more water polluting industries might have higher levels of water pollution, while provinces with more air polluting industries might have more air pollution. In addition, the water distribution in China is largely uneven. There is a shortage of surface and underground water in the northern part of China. For example, in Beijing, we will only see air pollution not much water pollution, since the Yongding River in Beijing has dried up. However, if we just look at the southern part, we may find a closer correlation between air and water pollution, i.e., less developed areas have less water and air pollution, while developed areas such as Shanghai have both high water and air pollution.

${ }^{17}$ The province-specific fixed effects capture unmeasured locational attributes or attributes that are non-time varying (e.g., north/south or coast/non-coast location) during the period of analysis.

${ }^{18}$ See Dasgupta et al. (2002) for a review.
} 
we exclude these other factors from equation (1) to focus on the total effect of income on emissions. $^{19}$

\section{Analysis of Results}

Table 4 contains the empirical results. ${ }^{20}$ F-tests indicate the inclusion of province-specific fixed effects is appropriate as the null hypothesis that the province-specific fixed effects are the same is rejected at the one percent significance level (the F statistic range from 4.56 to 137.71 for the cubic specification). Hausman tests of the null hypothesis that province characteristics are uncorrelated with income are also rejected in four of the models at the one percent significance level (for the cubic model, the Hausman test statistic range from 3.12 to 93.02). This is indicative of the appropriateness of using the fixed effects model (versus the random effects model). The one-way fixed effects model controls for unmeasured province characteristics whereas the one-way random effects model treats these unmeasured characteristics as a component of the error term (see Greene 2000, for details). We focus on the results for four pollutants below: total industrial waste water, industrial COD, waste gas, and industrial dust. This is because at least one of the income terms is statistically significant in all models dealing with these four pollutants. We also focus on the results from the cubic regressions (column (2) in Table 4) as the cubic term is statistically

\footnotetext{
${ }^{19}$ We are aware of the limitations of using equation (1) to estimate EKCs, see e.g., Stern (2004). In particular, equation (1) assumes that the slopes of the EKCs are homogenous across the Chinese provinces. Using crosscountry (e.g., Dijkgraaf and Vollegergh 2005) and cross-state panel data (e.g., List and Gallet 1999), studies have shown parameter heterogeneity across the cross-sectional units for selected pollutants. We do not implement slope heterogeneity in this paper. Equation (1) is less likely to provide biased and inconsistent estimates since our crosssection units belong to a single country and not a cross-section of countries observed over time. The assumption of a common slope among cross-section units is more believable within than between countries. Also, given China's political set-up (that is, local government officials being basically appointed by the central government), pollution policies across Chinese provinces are expected to be less heterogeneous than pollution policies across US states.

${ }^{20}$ The province-specific fixed effects are available upon request. An unbalanced panel is estimated for all six models as pollution data are not available for selected provinces in selected years. Since missing data are at most only $12 \%$ (for industrial COD) of the 270 possible observations (30 provinces by 9 years), we do not think the results obtained are biased and inefficient. As a robustness check, we also omit observations whose standardized residuals are greater than 4 . The results are qualitatively similar to those in Table 4.
} 
significant in the regressions for these four pollutants. The (within group) R-square values of these models range from 0.10 to $0.41 .^{21}$

\section{Table 4 near here}

\section{Estimated Environmental Kuznets Curves}

Substituting the estimated coefficients into equation (1), the estimated per capita emission values can be determined. Figure 1A contains the actual and estimated values of the industrial waste water per capita discharge from 1987 to $1995 .^{22}$ Although the cubic term is statistically significant, the coefficient estimate of the linear term for income dominates both the coefficient estimates of the square and cubic income terms. That is, the estimated industrial waste water per capita discharge declines with a rise in real income.

The actual and estimated values of the industrial COD per capita discharge appear in Figure 1B. A turning point in the estimated income-emission regression is evident here. A per capita discharge peak is observed at per capita income 556 yuan (in 1950 prices). According to the estimated income-emission regression, industrial COD per capita emission is expected to decline as per capita income increases up to 3,291 yuan (the maximum real per capita income observed during the period). This is consistent with Wang and Wheeler's (2003) finding that COD pollution intensity across China’s provinces declined between 1987-89 and 1992-1995.

The authors attribute this to increases in the pollution levy rates as income increase. As they

\footnotetext{
${ }^{21}$ A two-way fixed effects panel is also estimated. In three of the models (industrial waste water, waste gas, and industrial dust), results indicate the appropriateness of including the time-specific fixed effects. These time effects capture unmeasured macroeconomic factors (e.g., change in environmental laws emanating from the central government) that all provinces experience. However, when the time effects are included, the income variables (linear, square, and cubic terms) lose their significance. This suggests that the effects of changes in macroeconomic factors dominate those of changes in income as far as these types of emissions are concerned. With this result in mind, we focus on the one-way fixed effects panel results since income is an important variable in the EKC regressions.

${ }^{22}$ To focus on the relationship between income and emissions, unless indicated otherwise, all estimated values referred to in the paper exclude the estimated province-specific fixed effects.
} 
suggest, "[t]he locally enforced price of pollution rises steadily with development because enforcement capacity and community valuation of damage both increase.” (p. 466)

The coefficient estimate of the linear term for income once again dominates those of the square and cubic terms in the waste gas per capita discharge regression. From Figure 1C, we observe that emission per capita is expected to increase with real income. This result is consistent with those found by De Groot et al. (2004) who use a slightly longer data series (1982-1997) for Chinese provinces. They also find that waste gas increase monotonically with per capita income.

Two turning points are evident in the estimated industrial dust per capita discharge regression, see Figure 1D. For the per capita income (at the 1950 constant price) range observed between 1987 and 1995, we see a per capita emission trough at 1,295 yuan and peak at 2,505 yuan. These suggest that per capita emission at first decreases as per capita income increases up to 1,295 yuan; emission then increases with income, and reach its maximum at per capita income of 2,505 yuan; and, emission is expected to decrease as income increases up to the observe maximum per capita income of 3,291 yuan.

\section{Figures 1A to 1D near here}

Using the estimated emission-income relationships, off-sample (1996 to 2004) predictions of per capita emission values are calculated. In other words, if the estimated incomeemission relationship remained the same after 1995, what are the expected per capita emission levels for each of these four pollutants? How do these compare with the actual per capita emission levels in 1996 to 2004? Since data for waste gas are no longer available after 1995, we can make such comparisons only for three pollutants. ${ }^{23}$

\footnotetext{
${ }^{23}$ By limiting our sample to 1987 to 1995, it is possible that we are not capturing the entire range of the EKCs. For example, if a cubic relationship exists between income and emissions, it is possible that we capture only the first increasing (decreasing) portion of the EKC and completely miss the subsequent declining (increasing) portion of the
} 
The estimated cubic EKC for industrial waste water predicts a decline in per capita emission as income increases up to the observed maximum real per capita income level of 8,343 yuan. In fact, the model predicts negative per capita emissions when income reaches around 3,000 yuan. Practically, this result suggests that if no changes occur (in the income-emission relationship), industrial waste water emissions per capita is expected to be negligible at around 3,000 yuan. ${ }^{24}$ Figure $2 \mathrm{~A}$ contains the actual and off-sample predictions (using the average province-specific fixed effects) excluding 22 observations with negative predicted values.

The estimated cubic EKC (using the average province-specific fixed effects) for industrial dust also predicts a decline in per capita industrial dust discharge as income increases beyond 3,291 yuan; and, per capita industrial dust discharge is also expected to be insignificant at around 3,280 yuan. Observations with negative predicted values are excluded in Figure 2B.

Although the estimated EKC for industrial COD indicates that per capita industrial COD discharge declines as income increases up to 3,291 yuan (see Figure 1B), we see from Figure 2C that the estimated EKC for industrial COD (using the average province-specific fixed effects) show a rise in per capita discharge as income increases beyond 3,291 yuan (the observed maximum per capita income in the $1987-1995$ period). ${ }^{25}$

\section{Figures 2A to 2C near here}

Note that the estimates in Figures 2A to 2C also assume that the province-specific fixed effects remain the same between 1996 and 2004. Recall that the province-specific fixed effects

EKC by limiting the data period to 1987 to 1995 . To address this issue, we also estimate EKCs for these three pollutants using data for the entire 1987-2004 period. The results are qualitatively similar to those using the shorter sample-industrial waste water pollution increases then declines with an increase in income; industrial COD pollution declines and increases with an increase in income; and, the industrial dust estimated EKC flattens; however, it still predicts a decline in emissions as income increases.

${ }^{24}$ This translates to 19,809 yuan in 2004 prices; this is roughly US \$2,390 at an exchange rate of 8.2768 yuan per US dollar.

${ }^{25}$ We exclude observations with real income per capita greater than 5,000 yuan in Figure 2C to highlight the curvature in the estimated EKC. Actual data for these five observations are significantly lower than the predicted values. 
for the most part capture the effect of unmeasured locational attributes; the effect of other factors that either did not or changed very little during the period of analysis (e.g., north/south location; local authorities' attitude towards pollution) are also subsumed in the province-specific fixed effects. Thus, the predicted values in Figures 2A to 2C are calculated also assuming that the province-specific fixed effects remain the same between 1996 and 2004. That is, the off-sample predictions are based on a counter-factual—-the relationship between income and emissions and the factors that are subsumed in the province-specific fixed effects remain the same (or changed very little) after 1995.

It is evident from Figure 2A that actual industrial waste water per capita discharge increases with income-this is opposite of the prediction of the EKC. This suggests that despite policies enacted by the Chinese government after $1995,{ }^{26}$ perhaps these have not been stringent enough to bring the per capita discharge levels down to the level provided by the estimated EKC.

Besides the adoption of stricter environmental rules, structural changes (e.g., sectoral changes in output) experienced by the Chinese economy between 1996 and 2004 could have contributed to the observed emission pattern. ${ }^{27}$ The emission-income relationships observed here is less likely due to structural changes. This is because large structural changes (i.e., shift to secondary industries) occurred in the early 1990s not after 1995. In particular, the share of secondary industries to total output in 1990 is $41.6 \%$; this increased to $48.5 \%$ in 1995; by 2004, the share increased to 52.9\% (see China National Bureau of Statistics 2005).

\footnotetext{
${ }^{26}$ For example, Article 16 of the amended Law on the Prevention and Control of Water Pollution authorized "national and provincial agencies to employ mass-based pollution control systems for water bodies that would not meet ambient standards even if all discharges met concentration-based effluent standards.” (Ma and Ortolano, 2000, p. 28) Prior to the amendment in 1996, China did not limit the mass (concentration and volume) flowrate of pollutants. Rather, concern was mostly over pollutant concentration.

${ }^{27}$ According to Dasgupta et al. (2002), "observed changes in pollution as per capita income rises could come from several different sources: shifts in the scale and sectoral composition of output, changes in technology within sectors, or the impact of regulation on pollution abatement.” (p. 152)
} 
Output growth (scale effect) could have also contributed to the observed emissionincome relationships. Once again, it is not likely that the observed patterns after 1995 are due to significant growth in output. This is because between 1980 and 2004, China experienced its highest annual GDP growth prior to 1996. For example, annual GDP growth reached a high of $15 \%$ in 1984 and 14\% in 1992. Annual growth rates after 1995 ranged from 7\% to 10\% (see World Bank 2005).

Actual industrial dust per capita discharge rates are larger than the predicted per capita discharge rates for most of the provinces between 1996 and 2004, see Figure 2B. This is inconsistent with the notion that given the adoption of stricter environmental regulations, actual emissions should be lower than the EKC predictions because the latter assumes no changes in environmental regulations. Although, it should be noted that actual per capita emissions are closer to the predicted per capita emission values at income levels beyond 2,000 yuan. And, a negative income-emission relationship is observed in the actual data.

Policies enacted to lower industrial COD pollution discharge appear to have been partly successful. ${ }^{28}$ That is, although actual per capita industrial COD pollution discharge rates are higher than the predicted EKC discharge rates (see Figure 2C), the differences are for the most part not large and actual emissions rates have not increased with income as the estimated EKC model predicts. According to Wang and Wheeler (2005), industrial COD pollution is considered the most important water pollutant in China and has been monitored very closely by the Chinese environmental regulators. In fact, mass-based limits on industrial COD was included in the Ninth Five Year Plan for Environmental Protection and Long Term Targets for the Year 2010 passed in 1996 (see Ma and Ortolano 2000).

${ }^{28}$ A World Bank study (2006) arrives at a similar conclusion and partly attributes the reduction to improved industrial processes. 
The above conclusions though need to be qualified. This is because the off-sample predictions were calculated assuming that the effect of factors that are subsumed in the provincespecific fixed effects on emissions remain the same (or changed very little) after 1995. If these are not the case, then the above conclusions may not be correct. To partly address this concern, we also estimate a cubic EKC for the three pollutants using 1996-2004 data. We find that the structures of the fixed effects in the first (1987-1995) and second (1996-2004) periods are similar for industrial waste water and industrial COD—-the Spearman (Pearson) correlations of the first and second period province-specific fixed effects are 0.91 (0.96) for industrial waste water, 0.72 (0.69) for industrial COD, and $0.26(0.27)$ for industrial dust. This increases confidence in the results presented above.

\section{Auxiliary Regressions}

Although China's State Environmental Protection Administration (SEPA) sets effluent standards, local governments have the right to set stricter standards. ${ }^{29}$ Thus, local conditions will have an influence on how stringent pollution prevention and control policies are. It was suggested earlier that the province-specific fixed effects could be related to provincial authorities' attitudes towards pollution control independent of income levels. Since the estimated fixed effects are parametric shifts, larger values indicate higher pollution discharge rates which could have resulted from less willingness to control pollution.

We test a number of additional hypotheses using the estimated province-specific fixed effects. In particular, we ask if the estimated province-specific fixed effects (which we take to be related to a province's commitment to control pollution) are related to a number of characteristics such as a province's north/south and coast/non-coast location, unemployment rate, urbanization rate, and industrial structure. These fixed effects may also be related to the relative

\footnotetext{
${ }^{29}$ See Muldavin (2000), Ma and Ortolano (2000), and Economy (2004) for details.
} 
importance of state-owned enterprises and foreign direct investment (FDI) in a province's economy; and, whether the provincial government is running a budget surplus/deficit. The following auxiliary regression model is estimated:

$$
\alpha_{i}=\phi+\theta^{\prime} \mathbf{Z}_{\boldsymbol{i}}+v_{i}
$$

where $\alpha_{i}$ are the estimated province-specific fixed effects from equation (1), regressors included in $\boldsymbol{Z}_{\boldsymbol{i}}$ are province attributes hypothesized to be related to emission levels and commitment to pollution control; and, $v_{i}$ is a well-behaved error term.

The raw data clearly show that northern and coastal provinces are dirtier, thus we include a province's location in the auxiliary regression. Since the problems caused by unemployment are immediate and visible while the problems caused by pollution may not be immediate and are less visible, provinces with higher unemployment rates are expected to be dirtier and may be less willing to enforce environmental protection laws. Urbanization may reduce pollution since urban areas have better sanitary facilities and people in urban areas usually use gas instead of coal. However, urbanization normally is accompanied by industrialization. More industries imply higher industrial pollution. Therefore, the correlation between the urbanization rate (proxied by population density) and emissions is ambiguous.

Provinces with a larger share of their output originating from secondary industries which includes manufacturing are expected to be more polluted than provinces with a smaller output share from secondary industries. The managers of China's SOEs are appointed by the central government. Thus, they may be more willing to follow pollution control rules. These enterprises also tend to have access to better pollution control technologies than other types of enterprises. Therefore, provinces with a larger share of their output coming from the SOEs are expected to have lower emissions. Since most foreign enterprises in China are from developed countries and 
these firms tend to have superior and cleaner technologies, provinces receiving relatively more FDI are expected to be cleaner.

Lester and Lombard (1990) argue that administrative units with greater fiscal resources may be more inclined to regulate pollution. This is because they are less dependent on polluters for tax revenues. In China, fiscal revenue shortage is the major obstacle for local government enforcement of environmental protection laws. Thus, provinces experiencing relatively large budget deficits are expected to be more polluted and may be less willing to control pollution.

To mitigate potential endogeneity between the estimated province-specific fixed effects and the above mentioned regressors, we use the average values of these regressors in 1982-1986. In other words, since the effects of these factors may also be subsumed in the estimated province-specific fixed effects, these variables are measured in periods prior to 1987. Also, since the province-specific fixed effects capture unmeasured province characteristics that either did not or changed very little, these variables should also not vary too much in each province. Some of these variables did not vary too much in each province. For example, the coefficients of variation for population density range from $1.3 \%$ (Jilin) to $4.5 \%$ (Beijing). The share of secondary industries to total regional output and the share of state-owned enterprises to total industrial output are also quite stable in most of the provinces. The provinces, however, experienced large changes in the rate of unemployment, the size of the budget surplus/deficit, and FDI relative to total regional output. For example, the coefficients of variation for the rate of unemployment range from 4.5\% (Guangdong) to $69.4 \%$ (Beijing).

The estimates for the full model appear in column (1) of Table 5. There is no indication of a misspecification, multicollinearity, or heteroskedasticity problem. The fit of the models are quite good and ranges from $59 \%$ to $62 \%$. Controlling for income, northern provinces, provinces 
with lower population densities, and provinces with smaller secondary industries shares have lower per capita industrial waste water pollution; industrial COD emissions per capita are lower in less urbanized areas; and, coastal provinces, provinces with larger secondary industries shares, and provinces experiencing smaller budget surpluses (or larger budget deficits) have larger industrial dust emissions per capita.

\section{Table 5 near here}

Since the rate of unemployment, the size of the budget balance and FDI relative to total output experienced large changes in most provinces, we exclude them from equation (2). The results appear in column (2) of Table 5. For the most part, the results for the remaining variables are qualitatively similar to those in column (1) for industrial waste water and industrial dust. Coast, secondary industries share, and SOEs share are now statistically significant in the industrial COD regression. Non-coastal provinces, provinces with smaller secondary industries shares, and smaller SOEs shares have lower industrial COD pollution per capita discharge rates. The latter is consistent with Wang and Wheeler's (2003) finding that state-owned plants are more pollution intensive. As a robustness check, we also test for the presence of influential observations using DFITS, Cook’s distance, and Welsch Distance. We exclude observations (Shanghai and Guangdong for the first two pollutants; and only Shanghai in industrial dust) when at least two of these tests identify them as influential observations. The estimates appear in column (3). Population density loses significance in the industrial waste water and industrial COD regressions but become significant in the industrial dust regression. The results for the remaining variables are qualitatively similar.

Overall, the results indicate that provinces in the north have lower levels of industrial waste water pollution, after controlling for income. Northern provinces do not have much water 
resources, i.e., water is much more precious for them compared to the southern provinces, and therefore, they may be more interested in controlling water pollution. Non-coastal provinces and provinces with smaller secondary industries shares have lower levels of all three types of pollutants. Contrary to expectations, provinces with higher state-owned enterprises shares have higher levels of industrial COD pollution. Finally, there is also some evidence that a province's industrial dust pollution level is related to its budget balance. Industrial dust is a local public "bad;" thus, local governments may have more incentives to regulate this pollutant. Therefore, administrative units with greater fiscal resources may be more inclined to regulate industrial dust pollution.

\section{Concluding Remarks}

This paper estimated environmental Kuznets curves using 1987-1995 data for Chinese provinces. Off-sample predicted values of selected pollutants for the period of 1996-2004 were compared with actual emission levels during this period. We find that actual industrial COD pollution per capita discharge rates in 1996-2004 have leveled off and do not increase with income as the estimated EKC predicts, indicating that environmental policies enacted by the Chinese government may have been partly successful. However, we also find that the actual industrial waste water and industrial dust per capita discharge rates in 1996-2004 were higher than the EKC predictions.

Auxiliary regressions show that conditional on income, northern provinces have lower industrial waste water pollution; non-coastal and provinces with smaller secondary industry shares have lower industrial (waste water, COD, and dust) pollution; provinces with smaller 
SOEs shares have lower industrial COD pollution; and, commitment to control industrial dust pollution is correlated with local governments' budget balance.

China's pollution should concern us all as pollution in China affects other countries. In 2001 for example, dust from China reached the United States. International coordination of environmental protection is necessary. However, to control pollution, the Chinese government must do more. First, more stringent rules are needed to fight industrial waste water and industrial dust pollution. Many environmental protection laws existing western countries have not been established in China. Some laws are incomplete, for example, without specifying the necessary punishments. Some laws are hard to enforce, because it is not possible to identify violators. ${ }^{30}$

Second, strengthen law enforcement. Some areas value economic development higher than environment and ignore violators of environmental protection laws. ${ }^{31}$ There have been reports of some administrators accepting bribes from violators and failing to enforce established laws on environmental protection.

Third, increase government spending on environmental protection. China's environmental protection expenditure was so small that it was only in 2006 that environmental protection expenditure became a formal government budgetary expenditure item (see China National Bureau of Environmental Protection 2006). Facing severe environmental deterioration and complaints from the general public, increasing government spending on environmental protection is imperative.

Finally, provide incentives to local governments for environmental protection. The role of local governments is crucial. Since fiscal resources are extremely limited, local governments in China simply do not have much incentive for environmental protection. Thus, one way to put

\footnotetext{
${ }^{30}$ A white paper issued by the State Council Information Office in 2006 summarizes what China has done to protect its environments in the last decade.

${ }^{31}$ See e.g., China Daily (2007).
} 
pressure on local governments to regulate pollution is to create a mechanism whereby central government transfers are tied not only to local output growth but to improvements in environmental outcomes as well. If appropriately constructed, this may prove popular with local government officials. There has been an attempt to control pollution by using green GDP. Green GDP accounts for pollution costs in GDP calculation. A recent official estimate puts the cost of pollution at 3\% of GDP in 2004 (see The Economist 2007). Green GDP, however, is a controversial measure-both in how it is calculated and in its use in evaluating the performance of local government officials. It is so controversial and unpopular that a report due in March 2007 has not been issued (see Kahn and Yardley 2007). Perhaps rather than using green GDP to measure local government officials' performance, a system rewarding those able to achieve targeted emission reductions would be more acceptable. 


\section{Data Appendix}

Data used in equation (2) are collected from China Compendium of Statistics 1949-2004. Unemployment rate is the ratio of the number of the registered unemployed persons to the labor force in urban areas. Population density is the number of people per square kilometer. Secondary share (in percent) is the share of secondary industry output to the total regional product. Secondary industry includes mining and quarrying, manufacturing, production and supply of electricity, water and gas, and construction. State enterprises share (in percent) is the size of the gross industrial output of state-owned enterprises to gross industrial output of all enterprises in the province. FDI share (in percent) is the size of actually used foreign direct investment to the region's total output. Budget balance share (in percent) is the size of the budget balance relative to the region's total output. Budget balance is the difference between the local government general revenue and expenditure. 


\section{References}

Cheng, Y., Chen, S., Guang, Y. (2007). Expected Decisions from the Two Meetings. Liaowang Dongfang Weekly Journal, March 12. (in Chinese)

China Daily (2007). Local Governments ‘Ignoring’ Green Model. China Daily, July 23. English version available at www.chinadaily.com.cn/china/2007-07/23/content_5441271.htm, last accessed August 27.

China Editorial Board of China Environmental Yearbook (Various years). Environmental Yearbook of China, Beijing: China Environmental Science Press. (in Chinese)

China National Bureau of Statistics (2005). China Compendium of Statistics 1949-2004, Beijing: China Statistics Press. (in Chinese)

China State Council Executive Office. (1998). Circular on Stopping Producing and Using Leaded Gas. Document No.129, September 2. (in Chinese)

China State Council Information Office (2006). Environmental Protection in China (1996-2005). English version available at www.china.org.cn/english/2006/Jun/170355.htm, last accessed January 18, 2007.

Dasgupta, S., Laplante, B., Wang, H., Wheeler, D. (2002). Confronting the Environmental Kuznets Curve. Journal of Economic Perspectives 16: 147-168.

De Bruyn, S.M., Heintz, R.J. (1999). The Environmental Kuznets Curve Hypothesis. In: J. van den Bergh (ed.), Handbook of Environmental and Resource Economics. Cheltenham, UK: Edward Elgar, 656-677.

De Groot, H.L.F., Withagen, C.A., Zhou, M. (2004). Dynamics of China's Regional Development and Pollution: An Investigation into the Environmental Kuznets Curve. Environment and Development Economics 9: 507-537.

Dijkgraaf, E., Vollegergh, H. (2005). A Test for Parameter Homogeneity in $\mathrm{CO}_{2}$ Panel EKC Estimations. Environmental and Resource Economics 32: 229-239.

Economist, The (2004). China’s Environment: A Great Wall of Waste, August 19.

Economist, The (2007). Grim Tales, March 31.

Economy, E. (2004). The River Runs Black: The Environmental Challenge to China's Future. Ithaca, NY: Cornell University Press.

Edmonds, R.L. (1999). The Environment in the People's Republic of China 50 Years On. China Quarterly 159: 640-649.

Greene, W.H. (2000). Econometric Analysis, Fourth Edition. Upper Saddle River, NJ: Prentice Hall.

Grossman, G.M., Krueger, A.B. (1995). Economic Growth and the Environment. Quarterly Journal of Economics 110: 353-377.

Lester, J.P., Lombard, E.N. (1990). The Comparative Analysis of State Environmental Policy. Natural Resources Journal 30: 301-319.

Kahn, J., Yardley, J. (2007). As China Roars, Pollution Reaches Deadly Extremes. The New York Times, August 26.

List, J.A., Gallet, C.A. (1999). The Environmental Kuznets Curve: Does One Size Fit All? Ecological Economics 31: 409-423.

List, J.A., McHone, W. (2000). Ranking State Environmental Outputs: Evidence from Panel Data. Growth and Change 31: 23-39.

Lynch, D.J. (2005). Pollution Poisons China’s Progress, USA Today, July 4. 
MacBean, A. (2007). China's Environment: Problems and Policies. The World Economy 30: 292-307.

Ma, X., Ortolano, L. (2000). Environmental Regulation in China: Institutions, Enforcement, and Compliance. Lanham, Maryland: Rowman \& Littlefield.

Millimet, D.L., List, J.A., Stengos, T. (2003). The Environmental Kuznets Curve: Real Progress or Misspecified Models? The Review of Economics and Statistics 85: 1038-1047.

Muldavin, J. (2000). The Paradoxes of Environmental Policy and Resource Management in Reform-Era China. Economic Geography 76: 244-271.

Naughton, B. (2007). The Chinese Economy. Cambridge, MA: The MIT Press.

Stern, D.I. (2004). The Rise and Fall of the Environmental Kuznets Curve. World Development 32: 1419-1439.

Wang, H., Wheeler, D. (2005). Financial Incentives and Endogenous Enforcement in China's Pollution Levy System. Journal of Environmental Economics and Management 49: 174-196.

Wang, H., Wheeler, D. (2003). Equilibrium Pollution and Economic Development in China. Environment and Development Economics 8: 451-466.

World Bank (2005). 2005 World Development Indicators CD-Rom. Washington, D.C.: The World Bank.

World Bank. (2006). China Water Quality Management: Policy and Institutional Considerations. Environment and Social Development Discussion Paper, September. 
Table 1. Summary Statistics, 30 Chinese Provinces from 1987 to 2004

\begin{tabular}{|c|c|c|c|c|}
\hline & Mean & $\begin{array}{l}\text { Standard } \\
\text { Deviation }\end{array}$ & $\begin{array}{l}\text { Coefficient } \\
\text { of Variation }\end{array}$ & Obs. \\
\hline \multicolumn{5}{|l|}{ A. 1987 to 1995} \\
\hline Real Income Per Capita (RGRPPC) ${ }^{1 /}$ & $696.634^{\mathrm{a} /}$ & 470.984 & 67.609 & 270 \\
\hline Total Industrial Waste Water (IWATER) ${ }^{2 /}$ & $22.549^{a /}$ & 17.504 & 77.624 & 269 \\
\hline Industrial COD (COD) ${ }^{3 /}$ & $0.007^{\mathrm{a} /}$ & 0.004 & 65.006 & 237 \\
\hline Waste Gas (GAS) ${ }^{4 /}$ & 10359.320 & 7372.472 & 71.168 & 268 \\
\hline Sulfur Dioxide $\left(\mathrm{SO}_{2}\right)^{3 /}$ & 0.016 & 0.010 & 63.752 & 267 \\
\hline Total Smoke (SMOKE) $)^{3 /}$ & $0.014^{a /}$ & 0.010 & 69.780 & 266 \\
\hline Industrial Dust (IDUST) $^{3 /}$ & 0.007 & 0.005 & 73.178 & 267 \\
\hline \multicolumn{5}{|l|}{ B. 1996 to 2004} \\
\hline Real Income Per Capita (RGRPPC) ${ }^{1 /}$ & 1421.518 & 1105.391 & 77.761 & 270 \\
\hline Total Industrial Waste Water (IWATER) ${ }^{2 /}$ & 16.307 & 10.905 & 66.876 & 270 \\
\hline Industrial COD (COD) ${ }^{3 /}$ & 0.005 & 0.004 & 70.309 & 270 \\
\hline Waste Gas (GAS) ${ }^{4 /}$ & NA & NA & NA & NA \\
\hline Sulfur Dioxide $\left(\mathrm{SO}_{2}\right)^{3 /}$ & 0.017 & 0.011 & 65.965 & 120 \\
\hline Total Smoke (SMOKE) ${ }^{3 /}$ & 0.009 & 0.007 & 71.197 & 120 \\
\hline Industrial Dust (IDUST) $^{3 /}$ & 0.007 & 0.004 & 62.155 & 269 \\
\hline
\end{tabular}

Notes: ${ }^{1 /} 1950$ yuan; ${ }^{2 /}$ Metric ton per capita; ${ }^{3 /}$ Ton per capita; ${ }^{4 /}$ Cubic meter per capita. ${ }^{a /}$ Means test indicates that means in 1987-1995 and 1996-2004 are significantly different at the 99\% confidence level. 
Table 2. Provincial Unconditional Rankings (Cleanest $=1$ to Dirtiest=30) in Various Pollutants, 1987-1995

\begin{tabular}{|c|c|c|c|c|c|c|}
\hline Province & IWATER & COD & GAS & $\mathrm{SO}_{2}$ & SMOKE & IDUST \\
\hline \multicolumn{7}{|l|}{ NORTH } \\
\hline Beijing $^{1 / 2 /}$ & 28 & 24 & 29 & 28 & 25 & 17 \\
\hline Tianjin ${ }^{1 / 2 /}$ & 24 & 29 & 25 & 26 & 23 & 9 \\
\hline Hebei ${ }^{1 / 2 /}$ & 11 & 7 & 20 & 17 & 16 & 23 \\
\hline Shanxi ${ }^{2 /}$ & 13 & 10 & 26 & 27 & 27 & 24 \\
\hline Inner Mongolia ${ }^{2 /}$ & 9 & 22 & 24 & 25 & 30 & 26 \\
\hline \multicolumn{7}{|l|}{ NORTHEAST } \\
\hline Liaoning $^{1 / 2 /}$ & 29 & 27 & 28 & 24 & 26 & 30 \\
\hline Jilin $^{2 /}$ & 17 & 28 & 23 & 13 & 28 & 16 \\
\hline Heilongjiang $^{2 /}$ & 23 & 23 & 22 & 11 & 29 & 18 \\
\hline \multicolumn{7}{|l|}{ EAST } \\
\hline Shanghai ${ }^{1 /}$ & 30 & 30 & 30 & 29 & 20 & 11 \\
\hline Jiangsu $^{1 /}$ & 27 & 19 & 16 & 19 & 15 & 10 \\
\hline Zhejiang $^{1 /}$ & 21 & 20 & 15 & 14 & 6 & 19 \\
\hline Anhui & 14 & 16 & 7 & 5 & 12 & 4 \\
\hline Fujian ${ }^{1 /}$ & 19 & 18 & 8 & 3 & 4 & 5 \\
\hline Jiangxi & 16 & 6 & 6 & 10 & 11 & 21 \\
\hline Shandong ${ }^{1 / 2 /}$ & 3 & 21 & 17 & 23 & 19 & 8 \\
\hline \multicolumn{7}{|c|}{ CENTRAL AND SOUTH } \\
\hline Henan ${ }^{2 /}$ & 5 & 8 & 9 & 4 & 9 & 3 \\
\hline Hubei & 26 & 11 & 12 & 12 & 8 & 13 \\
\hline Hunan & 25 & 12 & 5 & 9 & 5 & 12 \\
\hline Guangdong $^{1 /}$ & 18 & 15 & 13 & 7 & 3 & 22 \\
\hline Guangxi $^{1 /}$ & 20 & 26 & 3 & 15 & 10 & 28 \\
\hline Hainan ${ }^{1 /}$ & 8 & 25 & 2 & 2 & 2 & 1 \\
\hline \multicolumn{7}{|l|}{ SOUTHWEST } \\
\hline Sichuan & 22 & 14 & 14 & 22 & 17 & 15 \\
\hline Guizhou & 2 & 3 & 11 & 21 & 13 & 14 \\
\hline Yunnan & 6 & 9 & 4 & 8 & 7 & 2 \\
\hline Tibet & 1 & 1 & 1 & 1 & 1 & 6 \\
\hline \multicolumn{7}{|l|}{ NORTHWEST } \\
\hline Shaanxi ${ }^{2 /}$ & 7 & 4 & 10 & 20 & 21 & 7 \\
\hline Gansu $^{2 /}$ & 12 & 5 & 21 & 18 & 14 & 25 \\
\hline Qinghai ${ }^{2 /}$ & 10 & 2 & 18 & 6 & 22 & 27 \\
\hline Ningxia $^{2 /}$ & 15 & 13 & 27 & 30 & 24 & 29 \\
\hline Xinjiang $^{2 /}$ & 4 & 17 & 19 & 16 & 18 & 20 \\
\hline
\end{tabular}

Notes: ${ }^{1 /}$ Coastal province. ${ }^{2 /}$ Northern province. Classifications adopted from De Groot et al. (2004). 
Table 3. Spearman Rank Correlation Coefficients, 30 Chinese Provinces from 1987 to 1995

\begin{tabular}{lrrrrrr}
\hline & IWATER & COD & GAS & $\mathrm{SO}_{2}$ & SMOKE & IDUST \\
& & & & & & \\
IWATER & 1.000 & & & & & \\
$\mathrm{COD}$ & $0.564^{\mathrm{a} /}$ & 1.000 & & & & \\
GAS & $0.383^{\mathrm{b} /}$ & $0.404^{\mathrm{b} /}$ & 1.000 & & & \\
$\mathrm{SO}_{2}$ & 0.298 & $0.318^{\mathrm{c} /}$ & $0.774^{\mathrm{a} /}$ & 1.000 & & \\
SMOKE & 0.180 & $0.321^{\mathrm{c} /}$ & $0.825^{\mathrm{a} /}$ & $0.705^{\mathrm{a} /}$ & 1.000 & \\
IDUST & 0.212 & 0.022 & $0.518^{\mathrm{a} /}$ & $0.428^{\mathrm{b} /}$ & $0.467^{\mathrm{a} /}$ & 1.000 \\
& & & & & & \\
\hline
\end{tabular}

Notes: ${ }^{\mathrm{a} / \mathrm{b} / \mathrm{c} /}$ Significant at the 99\%, 95\%, and 90\% confidence levels, respectively. 
Table 4. Fixed effects panel regression estimates ${ }^{1 /}$

\begin{tabular}{|c|c|c|c|c|c|c|}
\hline & \multicolumn{2}{|c|}{ IWATER } & \multicolumn{2}{|c|}{ COD } & \multicolumn{2}{|c|}{ GAS } \\
\hline & (1) & (2) & (1) & $(2)$ & (1) & $(2)$ \\
\hline Income & $\begin{array}{c}-1.14 \mathrm{E}-02^{\mathrm{a}} \\
(2.34 \mathrm{E}-03)\end{array}$ & $\begin{array}{c}-3.23 \mathrm{E}-02^{\mathrm{a}} \\
(5.15 \mathrm{E}-03)\end{array}$ & $\begin{array}{r}-8.56 \mathrm{E}-07 \\
(2.03 \mathrm{E}-06)\end{array}$ & $\begin{array}{r}8.86 \mathrm{E}-06 \\
(5.39 \mathrm{E}-06)\end{array}$ & $\begin{array}{l}8.49^{a /} \\
(1.17)\end{array}$ & $\begin{array}{r}15.90^{\mathrm{a} /} \\
(3.97)\end{array}$ \\
\hline Income $^{2}$ & $\begin{array}{r}-1.20 \mathrm{E}-07 \\
(9.40 \mathrm{E}-07)\end{array}$ & $\begin{array}{l}1.69 \mathrm{E}-05^{a /} \\
(3.90 \mathrm{E}-06)\end{array}$ & $\begin{array}{r}-1.38 \mathrm{E}-09^{\mathrm{a} /} \\
(5.09 \mathrm{E}-10)\end{array}$ & $\begin{array}{r}-9.29 \mathrm{E}-09^{b /} \\
(3.67 \mathrm{E}-09)\end{array}$ & $\begin{array}{r}-6.25 \mathrm{E}-04 \\
(4.35 \mathrm{E}-04)\end{array}$ & $\begin{array}{r}-6.65 \mathrm{E}-03^{6} \\
(3.32 \mathrm{E}-03)\end{array}$ \\
\hline Income $^{3}$ & - & $\begin{array}{c}-3.40 \mathrm{E}-09^{a /} \\
(7.65 \mathrm{E}-10)\end{array}$ & - & $\begin{array}{l}1.58 \mathrm{E}-12^{\mathrm{b}} \\
(6.81 \mathrm{E}-13)\end{array}$ & - & $\begin{array}{l}1.20 \mathrm{E}-06^{\mathrm{c}} \\
(6.71 \mathrm{E}-07)\end{array}$ \\
\hline Constant & $\begin{array}{r}30.57^{\mathrm{a} /} \\
(1.10)\end{array}$ & $\begin{array}{r}36.75^{a /} \\
(1.74)\end{array}$ & $\begin{array}{r}0.01^{\mathrm{a} /} \\
0.00\end{array}$ & $\begin{array}{l}0.01^{\mathrm{a} /} \\
(0.00)\end{array}$ & $\begin{array}{r}4871.76^{\mathrm{a} /} \\
(561.86)\end{array}$ & $\begin{array}{l}2684.47^{b /} \\
(1188.92)\end{array}$ \\
\hline F-statistic ${ }^{2 /}$ & $138.93^{a /}$ & $137.71^{a /}$ & $8.12^{a /}$ & $8.32^{\mathrm{a} /}$ & $84.30^{a /}$ & $86.34^{\mathrm{a} /}$ \\
\hline Hausman test statistic ${ }^{3 /}$ & $92.74^{\mathrm{a} /}$ & $93.02^{\mathrm{a} /}$ & $40.34^{a /}$ & $45.99^{\mathrm{a} /}$ & $8.40^{\mathrm{b} /}$ & $10.55^{b /}$ \\
\hline R-sq.--within & 0.349 & 0.393 & 0.113 & 0.128 & 0.389 & 0.408 \\
\hline R-sq.--between & 0.710 & 0.618 & 0.457 & 0.370 & 0.585 & 0.558 \\
\hline Obs. & 269 & 269 & 237 & 237 & 268 & 268 \\
\hline
\end{tabular}


Table 4, continued. Fixed effects panel regression estimates ${ }^{\text {a/ }}$

\begin{tabular}{|c|c|c|c|c|c|c|}
\hline & \multicolumn{2}{|c|}{$\mathrm{SO} 2$} & \multicolumn{2}{|c|}{ SMOKE } & \multicolumn{2}{|c|}{ IDUST } \\
\hline & (1) & $(2)$ & (1) & $(2)$ & (1) & $(2)$ \\
\hline Income & $\begin{array}{l}8.88 \mathrm{E}-06^{\mathrm{a}} \\
(1.83 \mathrm{E}-06)\end{array}$ & $\begin{array}{l}1.52 \mathrm{E}-05^{\mathrm{b}} \\
(6.35 \mathrm{E}-06)\end{array}$ & $\begin{array}{r}7.52 \mathrm{E}-07 \\
(1.96 \mathrm{E}-06)\end{array}$ & $\begin{array}{r}3.92 \mathrm{E}-06 \\
(7.41 \mathrm{E}-06)\end{array}$ & $\begin{array}{c}-1.35 \mathrm{E}-05^{\mathrm{a}} \\
(2.75 \mathrm{E}-06)\end{array}$ & $\begin{array}{r}-3.59 \mathrm{E}-05^{\mathrm{a}} \\
(9.19 \mathrm{E}-06)\end{array}$ \\
\hline Income $^{2}$ & $\begin{array}{r}-1.39 \mathrm{E}-09^{\mathrm{a}} \\
(4.79 \mathrm{E}-10)\end{array}$ & $\begin{array}{r}-6.53 \mathrm{E}-09 \\
(5.10 \mathrm{E}-09)\end{array}$ & $\begin{array}{r}-6.22 \mathrm{E}-10 \\
(4.45 \mathrm{E}-10)\end{array}$ & $\begin{array}{r}-3.20 \mathrm{E}-09 \\
(6.02 \mathrm{E}-09)\end{array}$ & $\begin{array}{l}2.74 \mathrm{E}-09^{a} \\
(6.68 \mathrm{E}-10)\end{array}$ & $\begin{array}{l}2.09 \mathrm{E}-08^{\mathrm{a}} \\
(6.37 \mathrm{E}-09)\end{array}$ \\
\hline Income $^{3}$ & - & $\begin{array}{r}1.03 \mathrm{E}-12 \\
(9.92 \mathrm{E}-13)\end{array}$ & - & $\begin{array}{r}5.15 \mathrm{E}-13 \\
(1.16 \mathrm{E}-12)\end{array}$ & - & $\begin{array}{r}-3.64 \mathrm{E}-12^{\mathrm{a}} \\
(1.19 \mathrm{E}-12)\end{array}$ \\
\hline Constant & $\begin{array}{l}1.09 \mathrm{E}-02^{\mathrm{a} /} \\
(1.02 \mathrm{E}-03)\end{array}$ & $\begin{array}{l}9.02 \mathrm{E}-03^{\mathrm{a} /} \\
(1.94 \mathrm{E}-03)\end{array}$ & $\begin{array}{l}1.43 \mathrm{E}-02^{\mathrm{a}} \\
(1.16 \mathrm{E}-03)\end{array}$ & $\begin{array}{l}1.33 \mathrm{E}-02^{\mathrm{a}} \\
(2.22 \mathrm{E}-03)\end{array}$ & $\begin{array}{l}1.48 \mathrm{E}-02^{\mathrm{a} /} \\
(1.63 \mathrm{E}-03)\end{array}$ & $\begin{array}{l}2.14 \mathrm{E}-02^{\mathrm{a}} \\
(3.40 \mathrm{E}-03)\end{array}$ \\
\hline F-statistic ${ }^{2 /}$ & $65.75^{a /}$ & $64.09^{a /}$ & $64.61^{\mathrm{a} /}$ & $63.81^{a /}$ & $4.22^{\mathrm{a} /}$ & $4.56^{\mathrm{a} /}$ \\
\hline Hausman test statistic ${ }^{3 /}$ & 2.53 & 4.15 & 2.81 & 3.12 & $9.92^{\mathrm{a} /}$ & $12.31^{\mathrm{a} /}$ \\
\hline R-sq.--within & 0.081 & 0.085 & 0.006 & 0.007 & 0.074 & 0.103 \\
\hline R-sq.--between & 0.192 & 0.159 & 0.010 & 0.003 & 0.004 & 0.000 \\
\hline Obs. & 267 & 267 & 266 & 266 & 267 & 267 \\
\hline
\end{tabular}

Notes: The numbers in parentheses are robust standard errors. ${ }^{a / b / c /}$ Significant at the $99 \%$, 95\%, and $90 \%$ confidence levels, respectively. ${ }^{1 /}$ The province-specific fixed effects estimates are available upon request. ${ }^{2 /}$ This tests the null hypothesis that the province-specific fixed effects are the same. ${ }^{3 /}$ The Hausman test is used to test the fixed effects model against the random effects model. A significant Hausman test statistic favors the fixed effects model. 
Table 5. Correlates of the Estimated Province-Specific Fixed Effects in 1987-1995

\begin{tabular}{|c|c|c|c|c|c|c|c|c|c|}
\hline & \multicolumn{3}{|c|}{ Industrial Waste Water } & \multicolumn{3}{|c|}{ Industrial COD $^{1 /}$} & \multicolumn{3}{|c|}{$\underline{\text { Industrial Dust }}^{1 /}$} \\
\hline & (1) & (2) & (3) & (1) & (2) & (3) & (1) & (2) & (3) \\
\hline \multirow[t]{2}{*}{ North } & $-13.13^{a /}$ & $-9.41^{b / 2}$ & $-9.66^{\mathrm{b} /}$ & -0.09 & -0.10 & -0.08 & -0.18 & 0.24 & 0.21 \\
\hline & (4.14) & $(3.43)$ & $(3.55)$ & $(0.20)$ & $(0.14)$ & $(0.14)$ & $(0.17)$ & $(0.17)$ & $(0.14)$ \\
\hline \multirow[t]{2}{*}{ Coast } & 4.696 & $7.432^{b /}$ & $8.398^{\mathrm{b} /}$ & 0.363 & $0.501^{a /}$ & $0.450^{a /}$ & $0.658^{\mathrm{a} /}$ & $0.388^{b /}$ & $0.532^{a /}$ \\
\hline & (4.33) & (3.11) & (3.43) & $(0.21)$ & $(0.12)$ & $(0.13)$ & $(0.18)$ & $(0.15)$ & $(0.13)$ \\
\hline \multirow[t]{2}{*}{ Unemployment } & 0.477 & -- & -- & 0.019 & -- & -- & 0.079 & -- & -- \\
\hline & (1.69) & & & $(0.08)$ & & & $(0.07)$ & & \\
\hline \multirow[t]{2}{*}{ Population density } & $0.005^{a /}$ & $0.005^{\mathrm{a} /}$ & -0.003 & $0.000^{\mathrm{b} /}$ & $0.000^{\mathrm{a} /}$ & 0.001 & 0.000 & 0.000 & $-0.001^{a /}$ \\
\hline & $(0.00)$ & $(0.00)$ & $(0.01)$ & $(0.00)$ & $(0.00)$ & $(0.00)$ & $(0.00)$ & $(0.00)$ & $(0.00)$ \\
\hline \multirow[t]{2}{*}{ Secondary share } & $1.180^{a /}$ & $0.835^{\mathrm{a} /}$ & $0.885^{\mathrm{a} /}$ & 0.013 & $0.016^{\mathrm{b} /}$ & $0.013^{c /}$ & $0.035^{a /}$ & 0.011 & $0.018^{b /}$ \\
\hline & $(0.28)$ & $(0.16)$ & $(0.17)$ & $(0.01)$ & $(0.01)$ & $(0.01)$ & $(0.01)$ & $(0.01)$ & $(0.01)$ \\
\hline \multirow[t]{2}{*}{ State enterprises share } & 0.130 & 0.125 & 0.070 & 0.010 & $0.012^{b /}$ & $0.015^{\mathrm{b} /}$ & 0.001 & 0.002 & -0.007 \\
\hline & $(0.18)$ & $(0.15)$ & $(0.17)$ & $(0.01)$ & $(0.01)$ & $(0.01)$ & $(0.01)$ & $(0.01)$ & $(0.01)$ \\
\hline \multirow[t]{2}{*}{ FDI share } & 2.006 & -- & -- & 0.045 & -- & -- & 0.062 & -- & -- \\
\hline & $(2.91)$ & & & $(0.14)$ & & & $(0.12)$ & & \\
\hline \multirow[t]{2}{*}{ Budget balance share } & -0.053 & -- & -- & 0.007 & -- & -- & $-0.031^{b /}$ & -- & -- \\
\hline & $(0.35)$ & & & $(0.02)$ & & & $(0.01)$ & & \\
\hline \multirow[t]{2}{*}{ Constant } & $-58.84^{a /}$ & $-46.22^{a /}$ & $-42.59^{a /}$ & $-1.50^{c /}$ & $-1.78^{a /}$ & $-1.97^{a /}$ & $-2.03^{a /}$ & -0.83 & -0.29 \\
\hline & (15.71) & (13.39) & $(14.64)$ & $(0.75)$ & $(0.53)$ & $(0.57)$ & $(0.64)$ & $(0.65)$ & $(0.56)$ \\
\hline $\mathrm{N}$ & 23 & 30 & 28 & 23 & 30 & 28 & 23 & 30 & 29 \\
\hline F-statistic ${ }^{2 /}$ & $34.34^{a /}$ & $54.60^{a /}$ & $10.64^{\mathrm{a} /}$ & $7.58^{a /}$ & $20.35^{a /}$ & $7.13^{a /}$ & $4.93^{a /}$ & $4.59^{a /}$ & $9.02^{a /}$ \\
\hline Adj R & 0.92 & 0.90 & 0.64 & 0.71 & 0.77 & 0.53 & 0.59 & 0.38 & 0.59 \\
\hline Ramsey Reset ${ }^{3 /}$ & 2.28 & 0.70 & $2.72^{\mathrm{c} /}$ & 0.65 & 1.78 & 1.29 & 0.59 & 0.73 & 1.76 \\
\hline Breusch-Pagan ${ }^{4 /}$ & 0.43 & 0.01 & 0.85 & 0.85 & 0.66 & 0.95 & 1.80 & 1.80 & 0.74 \\
\hline Mean VIF & 3.50 & 1.94 & 1.97 & 3.50 & 1.94 & 1.97 & 3.50 & 1.94 & 1.98 \\
\hline
\end{tabular}


Figure 1A. Total Industrial Waste Water Per Capita Discharge Actual and Estimated, 1987-1995

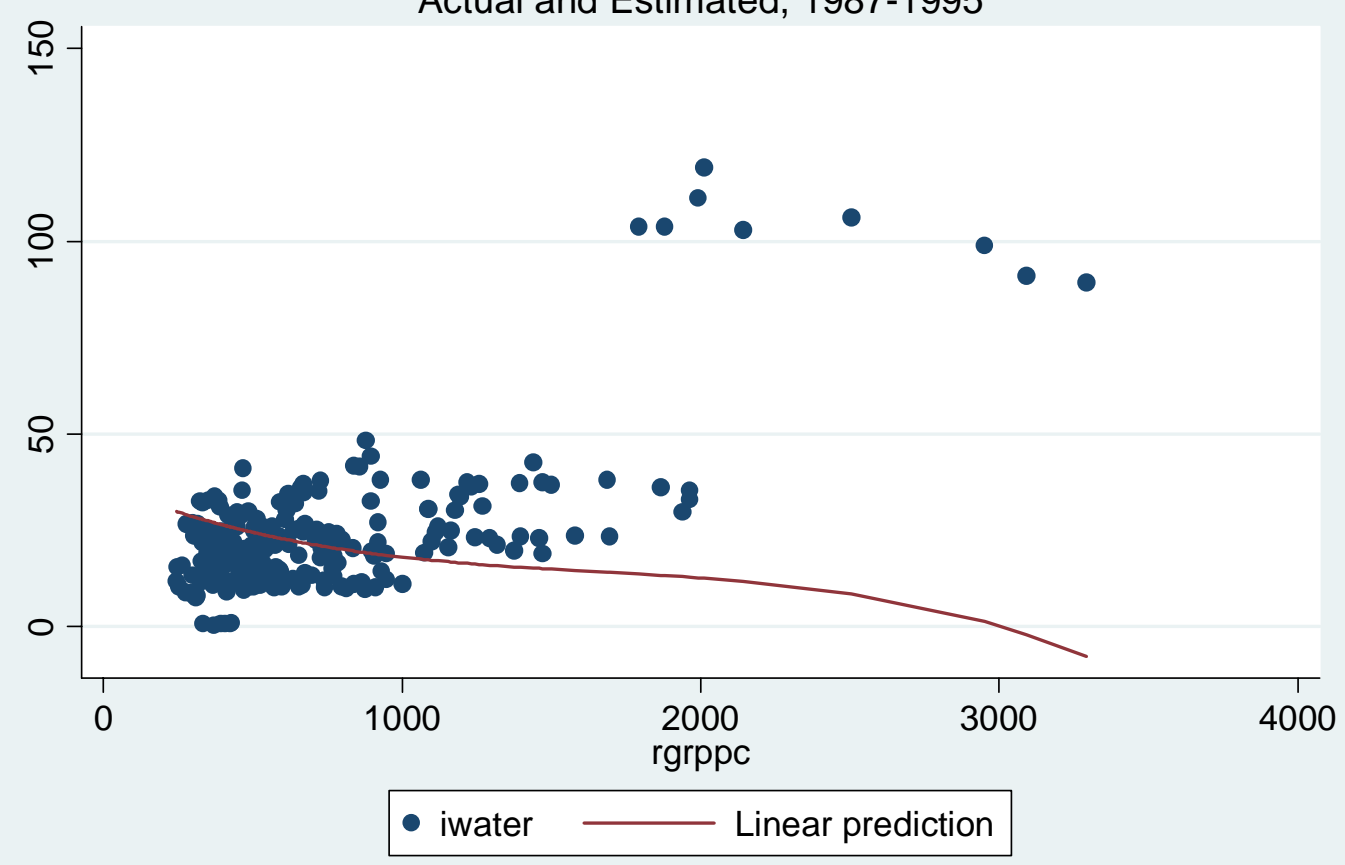


Figure 1B. Industrial COD Per Capita Discharge Actual and Estimated, 1987-1995

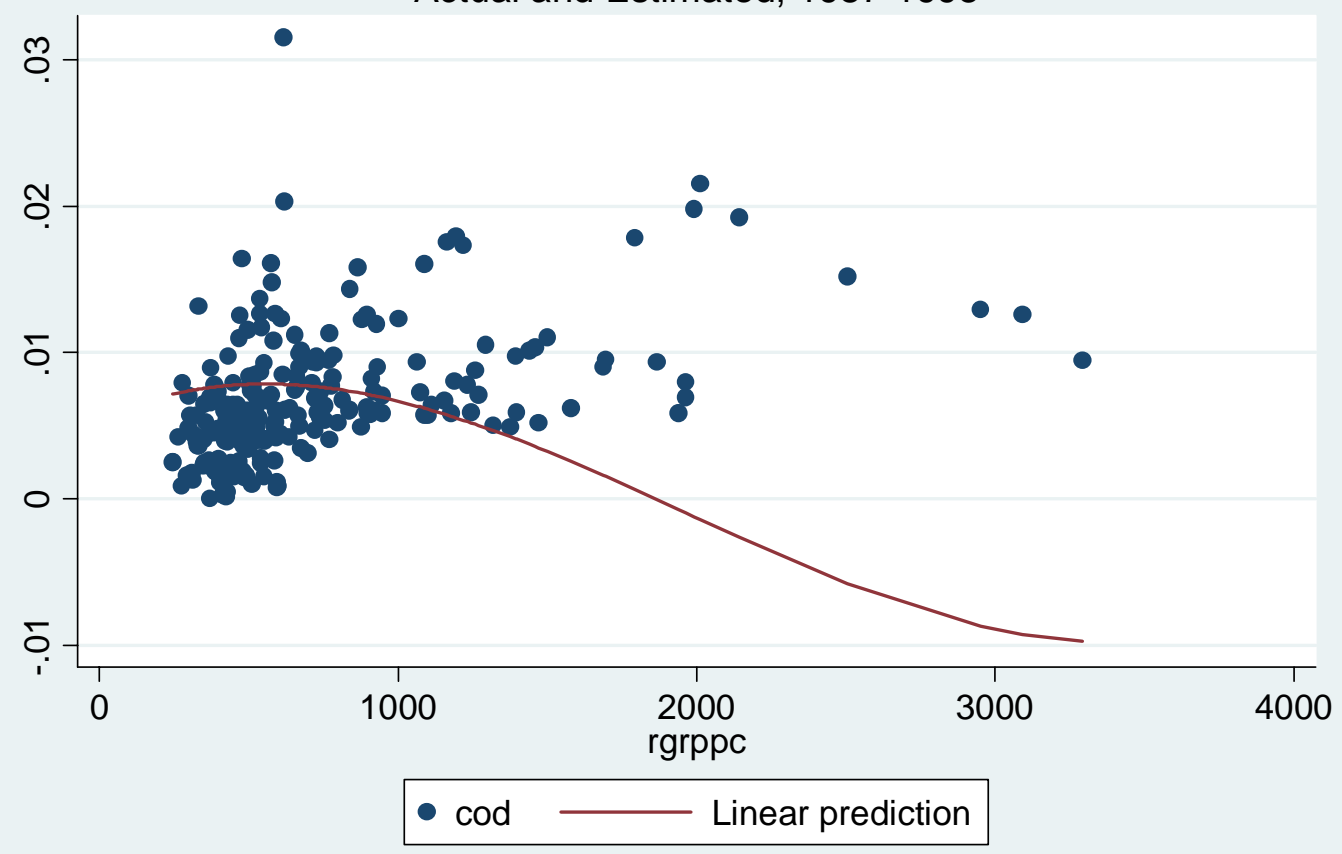


Figure 1C. Waste Gas Per Capita Discharge

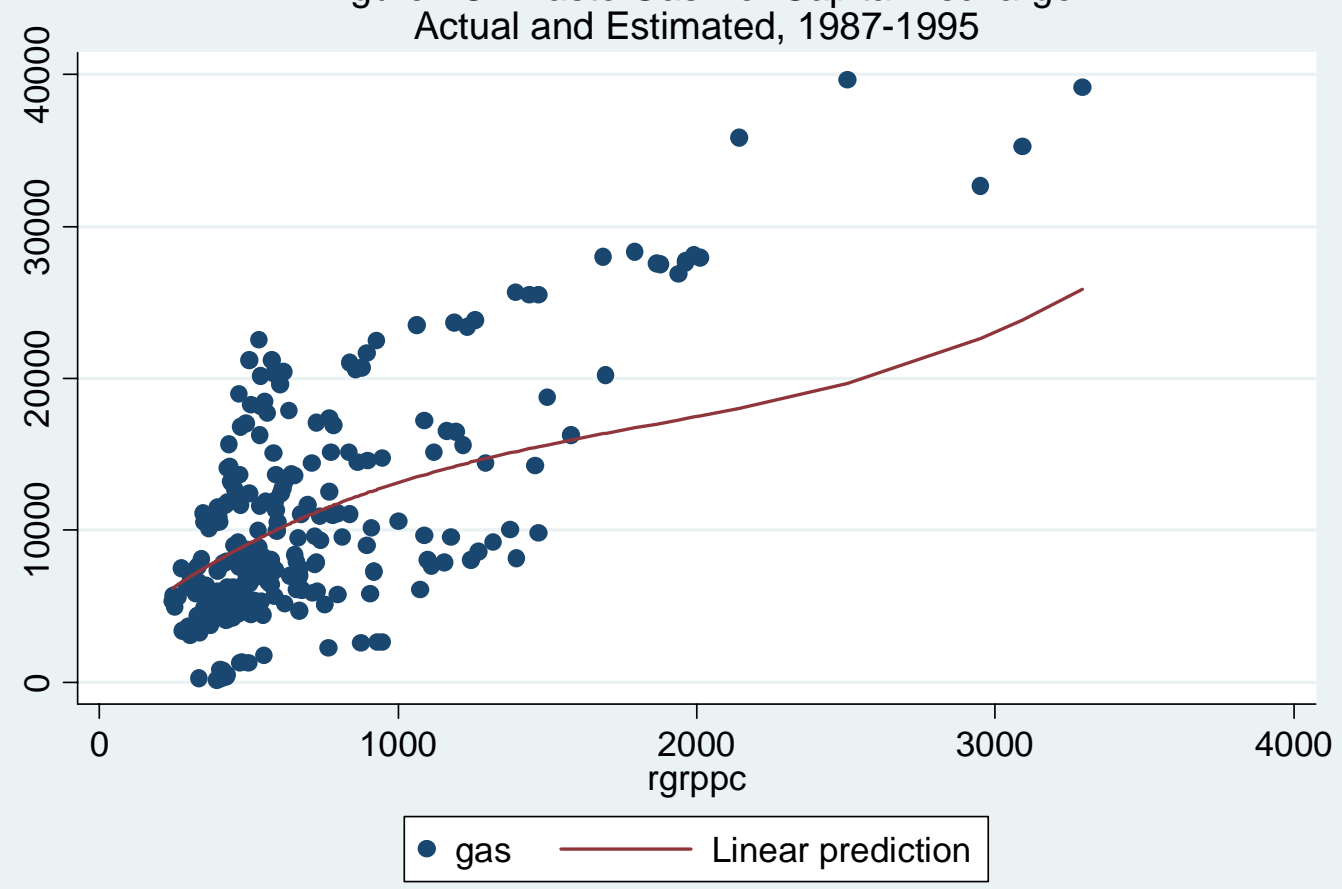


Figure 1D. Industrial Dust Per Capita Discharge Actual and Estimated, 1987-1995

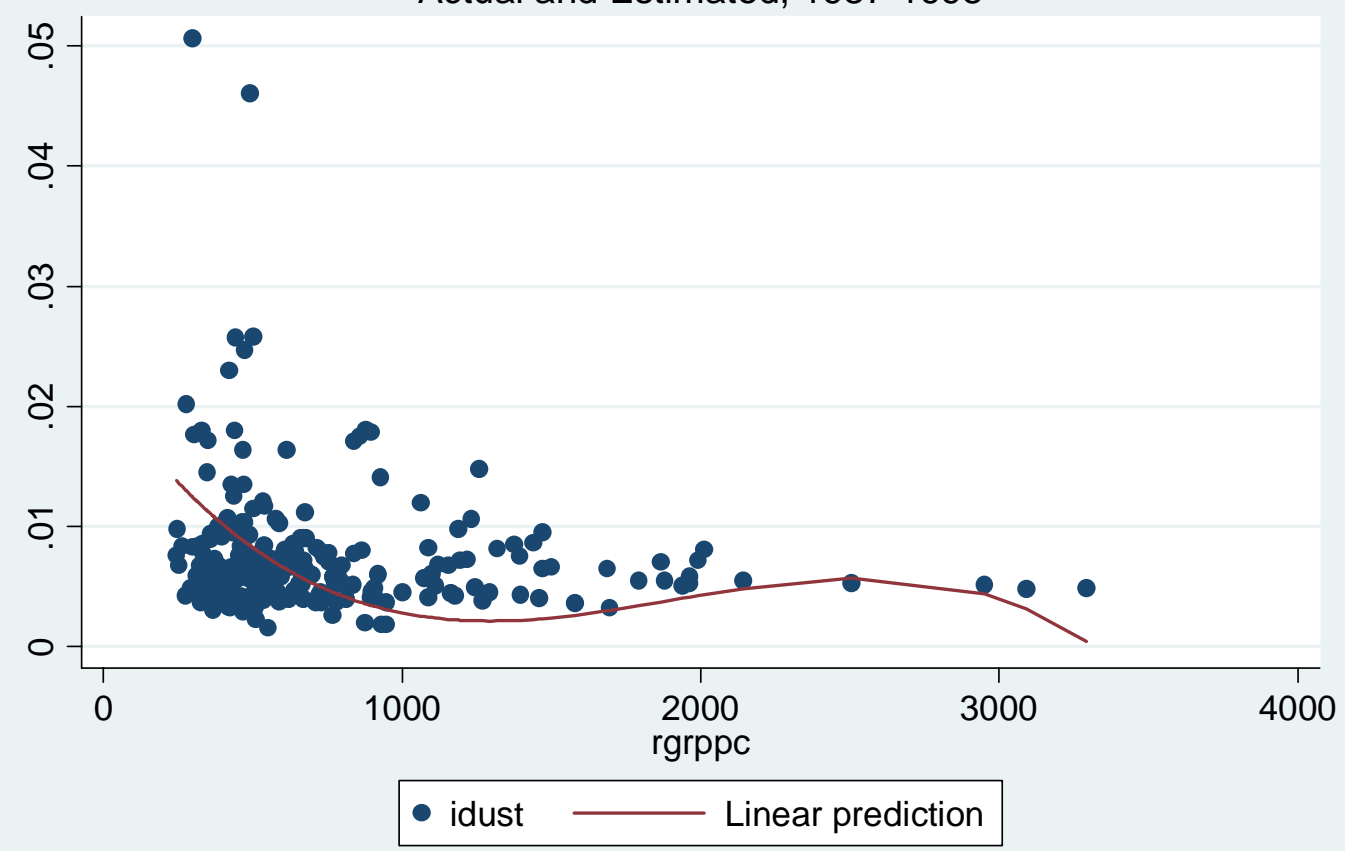


Figure 2A. Total Industrial Waste Water Per Capita Discharge Actual and Predicted, 1996-2004

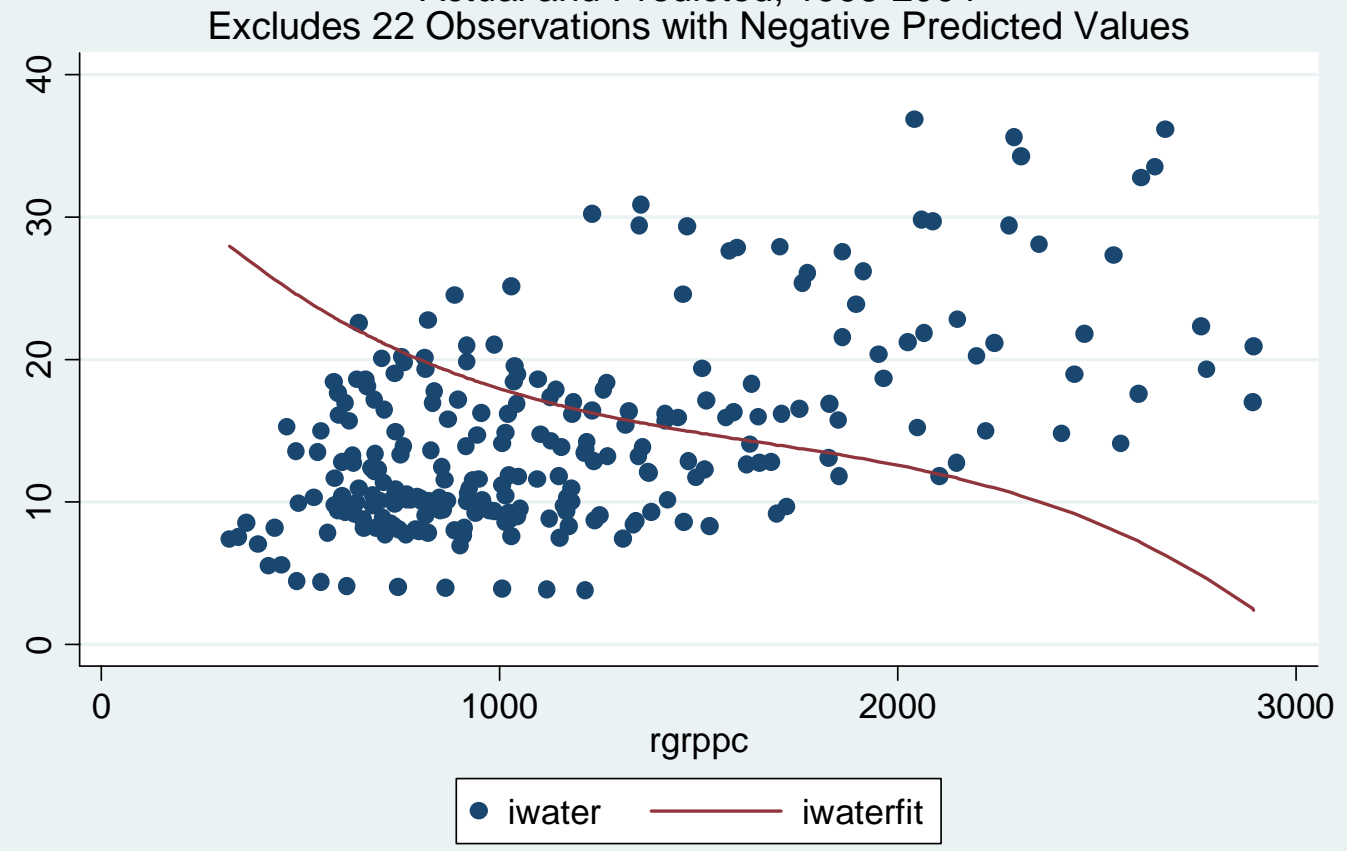


Figure 2B. Total Industrial Dust Per Capita Discharge Actual and Predicted, 1996-2004

Excludes 15 Observations with Negative Predicted Values

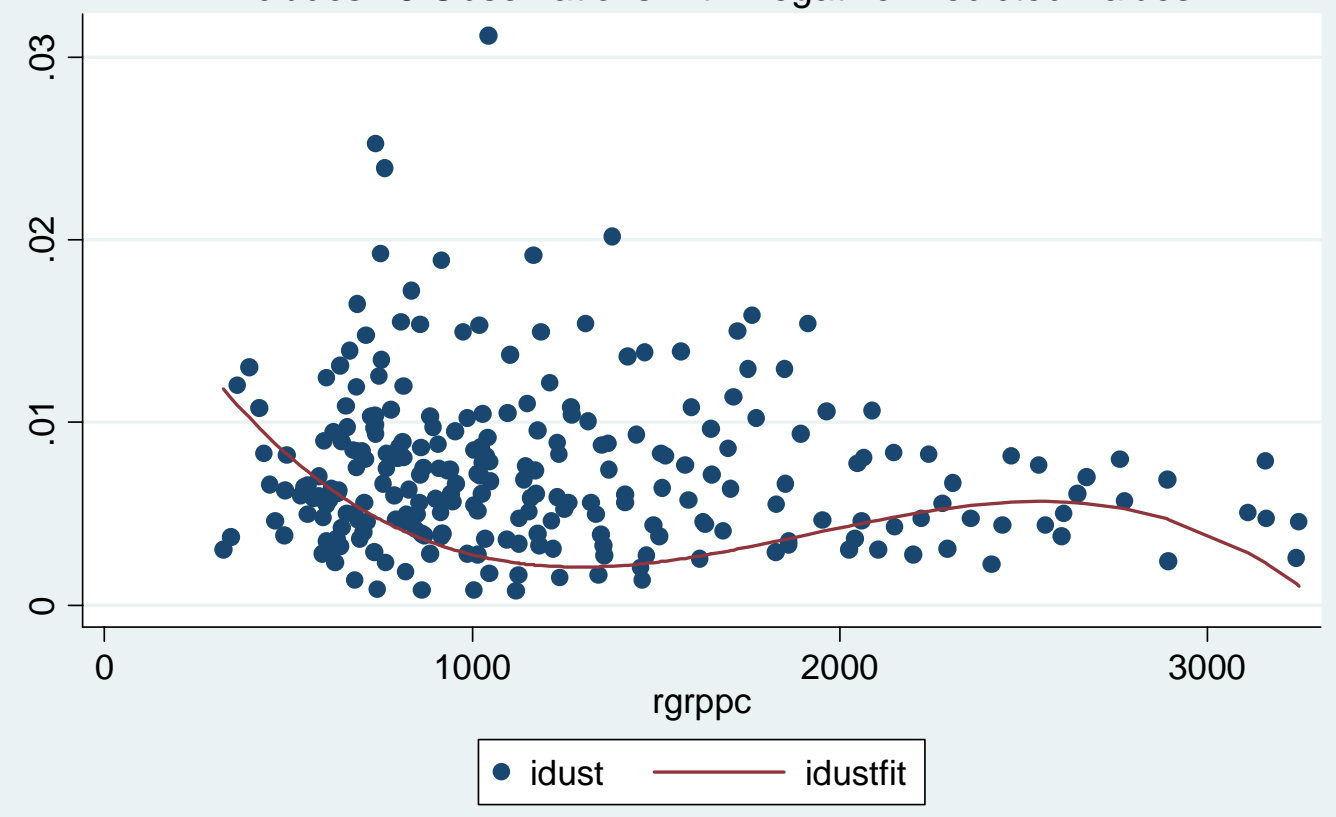


Figure 2C. Industrial COD Per Capita Discharge Actual and Predicted, 1996-2004

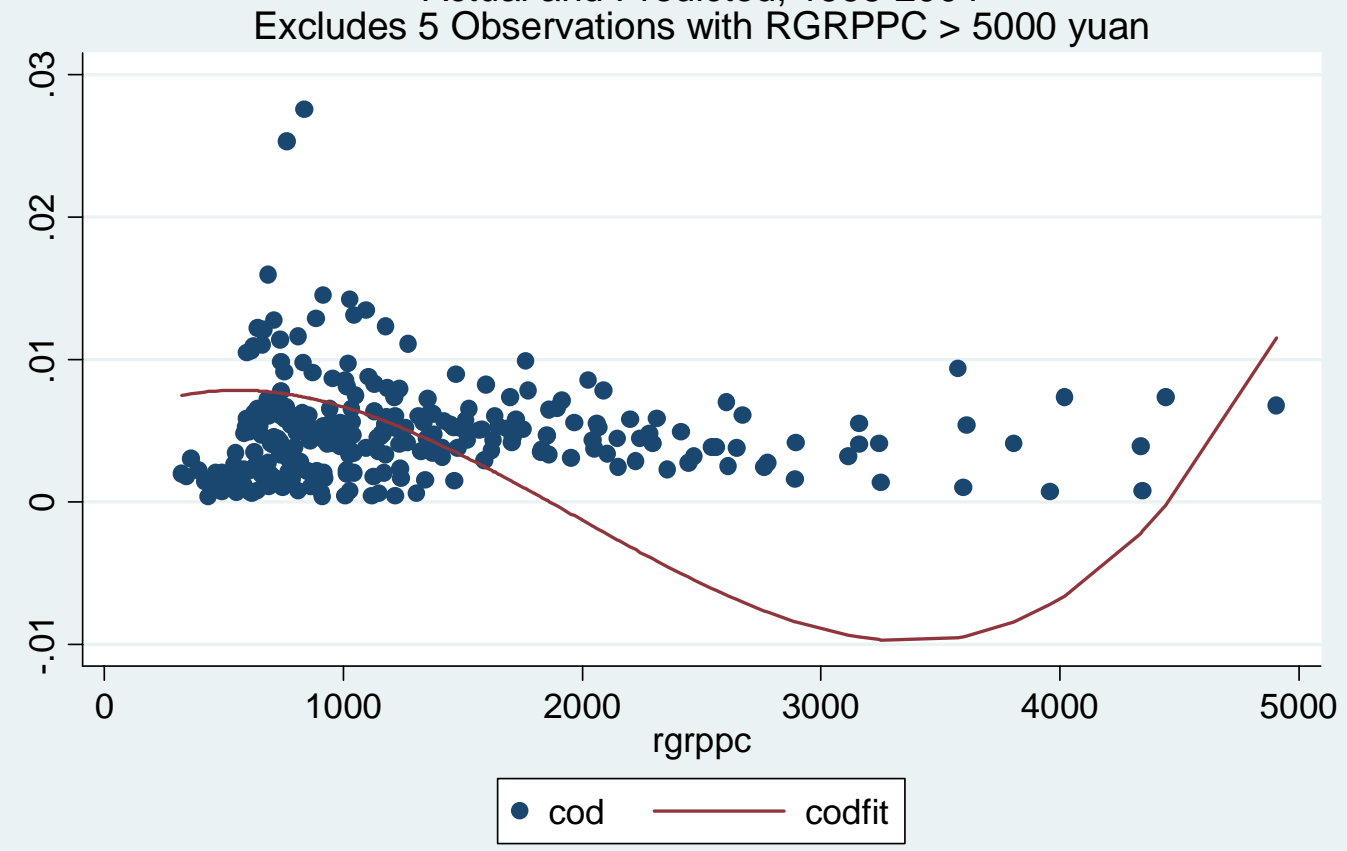

